\title{
Evaluating Genotoxic Effects of Plants Exposed to Heavy Metals and Polycyclic Aromatic Hydrocarbons at Dumpsite, Mechanic Workshop and Metal Scrap Site in Lagos
}

\author{
MUSTAPHA, NO; NJOKU, KL; *ADESUYI, AA; JOLAOSO, AO \\ Environmental Biology Research Unit, Cell Biology and Genetics Department, University of Lagos, Akoka, Lagos, Nigeria \\ *Corresponding Author Email: biologistalex@gmail.com
}

\begin{abstract}
Soil contamination from heavy metals and polycyclic aromatic hydrocarbons (PAHs) from dumpsite, automobile mechanic workshop and metal scrap sites pose human and ecological health risks. This study assesses the levels of heavy metals and PAHs in soils from these sites and their effects on the DNA yield and fragmentation of native plants around there. The DNA yield and fragmentation were compared to those obtained from non-polluted sites (control). DNA of the plants species, Musa acuminata (banana), Jatropha curcas (Barbados nut), Carica papaya (pawpaw), Axonopus compressus (carpet grass), Sida acuta (wireweed), and Eleucine indica (crabgrass grass) for polluted sites and control were analyzed using Gel electrophoresis. Soil heavy metals; copper $(\mathrm{Cu})$, zinc $(\mathrm{Zn})$, lead $(\mathrm{Pb})$ and chromium $(\mathrm{Cr})$ were evaluated from dumpsite, metal area and mechanic workshop using inductively coupled plasma-atomic emission spectrometry (ICP-AES). Polycyclic aromatic hydrocarbons were also determined from soils of the polluted sites using the GC/MS spectrophotometry. The result obtained from the DNA analysis showed that DNA yield and fragmentation of the polluted plants had higher indices than the controls which shows that heavy metals and polycyclic aromatic hydrocarbons affect the DNA of the plants. The effects of the pollutants on DNA of polluted plants had more smearing in their tissue than non-polluted plants. Heavy metals evaluation showed that zinc level was the highest in all the study sites; dumpsite, metal area and mechanic workshop $(5.146 \mathrm{mg} / \mathrm{kg}, 2.709 \mathrm{mg} / \mathrm{kg}$ and $1.990 \mathrm{mg} / \mathrm{kg}$ respectively) than the control ( $\mathrm{p}<0.05)$. Chromium was the least present $(0.022 \mathrm{mg} / \mathrm{kg}, 0.018 \mathrm{mg} / \mathrm{kg}$ and $0.002 \mathrm{mg} / \mathrm{kg}$ respectively). The results of this study indicate that dumpsite, mechanic workshop and metal scrap sites are potential sources of PAH and toxic metal, which can pose serious human health and ecological risks.
\end{abstract}

\section{DOI: https://dx.doi.org/10.4314/jasem.v23i2.21}

Copyright: Copyright (C) 2019 Mustapha et al. This is an open access article distributed under the Creative Commons Attribution License (CCL), which permits unrestricted use, distribution, and reproduction in any medium, provided the original work is properly cited.

Dates: Received: 30 December 2018; Revised: 30 January 2019; Accepted 02 February 2019

Keywords: DNA fragmentation, heavy metals, Gel electrophoresis, polycyclic aromatic hydrocarbon.

Pollution of the natural environment with foreign chemical substances (pollutants) can cause adverse change, disorder, harm or discomfort to the ecosystem (Adesuyi et al., 2015). Many wildlife and human populations as a result of this exposure to variety of these pollutants has led to a collection of biological effects (Mussali-Galante et al., 2013). Some of these pollutants are heavy metals, polychlorinated biphenyls (PCBs), polycyclic aromatic hydrocarbons (PAHs) etc. Among environmental pollutants, metals have been identified as the most toxic elements to nearly all living organisms (EPA, 2000). The increasing concern of the general public and of governments for the welfare of humans and natural environments requires the assessment of new, sensitive and efficient methods for early detection of environmental genotoxic risk. The difficulties arising from direct chemical measurements of pollutants in the field and the interpretation of such measurements in terms of bioavailability have stimulated strong interest in bioindicators and biomarkers (Labra et al., 2003).
Many metals are essential to living organisms but some of them are highly toxic or become toxic at high concentrations. These include iron $(\mathrm{Fe})$, Copper $(\mathrm{Cu})$, Zinc ( $\mathrm{Zn})$, Cobalt (Co), Molybdenum (Mo), and Manganese (Mn). Light metals such as Sodium (Na), Potassium $(\mathrm{K})$, and Calcium $(\mathrm{Ca})$ play important biological roles. Metals such as Mercury (Hg), Lead $(\mathrm{Pb})$, Nickel (Ni), Chromium ( $\mathrm{Cr})$, Cadmium $(\mathrm{Cd})$, and Arsenic (As) are generally not required for metabolic activity and are toxic to living organisms at quite low concentrations (Valavanidis and Vlachogianni 2010; Adesuyi et al., 2015). Other metals such as Vanadium (V) which is present in almost all-living organisms but its essentiality in cellular functions is yet to be established, is also capable of inducing toxic effects in various species (Mussali-Galante et al., 2013). Anthropogenic sources of heavy metals include like mining and smelting of metals, burning of fossil fuel, use of fertilizers and pesticides in agriculture, production of batteries and other metal products in industries, sewages sludge and municipal waste disposal (Shen 
et al., 2002; Adesuyi et al., 2016). Polycyclic aromatic hydrocarbons are also called polyaromatic hydrocarbons. These are organic compounds containing only carbons and hydrogen that are composed of aromatic rings (Fetzer, 2000). There are many sources of PAHs contamination in soils, which include fueling of vehicle, machines and domestic usage (Njoku et al., 2016). Oil pollution has a negative impact on the terrestrial environment ranging from aesthetic quantity in modification to death of sensitive biotic species (Briton, 1984). PAHs have been identified as carcinogenic and mutagenic and of potential adverse to health impacts and they include fluorene, phenanthrene, triphenylene, acenaphthene, and pyrene (Fetzer, 2000). Organisms integrate exposure to contaminants in their environment and respond in some measurable and predictable way, being these responses observed and measurable across different levels of biological organization (Bickham et al. 2000). For this reason, the use of biomarkers for environmental monitoring of individuals and populations exposed to chemical pollution has gained much attention in the last decades, because it offers great opportunities for a fast and sensitive detection of chemical stresses within organisms (Mussali-Galante et al., 2013). The use of biomarkers in environmental health was described in a series of publications issued by the Board of Environmental Studies in Toxicology of the National Research Council (NRC 1987, 1989) of the USA. The NRC defines biomarkers as "Indicators of events in biological systems or samples" and was further described as "tools that can be used to clarify the relationship, if any, between exposure to a xenobiotic substance and disease". Also, the NRC classified biomarkers into three categories based on their relation to the exposure-disease continuum: biomarkers of exposure, effect and susceptibility.

Bioindicators of contamination make it possible to detect subtle forms of pollution that are hard to measure in the field. Plants are good bioindicators because they play a significant role in food chain transfer and in defining habitat, they are easy to grow and adaptable to environmental stress, and they can be used for assaying a range of environmental conditions in different habitats. In addition, it has been shown that for some chemical agents, comparable results in terms of genetic abnormalities are obtained in plant or animal systems (Minissi and Lombi, 1997) and that plants are more sensitive to some stressors than animals (Wang and Freemark, 1995). Furthermore, plant-based assays applied to toxicity screening in the environmental field can be an appealing alternative to animals, reducing their sacrificing and saving costs (Kovalchuk and
Kovalchuk, 2008). The use of plants as bioindicators of genetic toxicity of environmental pollutants has been reported in several studies (Grant, 1994; Knasmuller et al., 1998; Labra et al., 2003; Valverde and Rojas, 2009; Valavanidis and Vlachogianni, 2010). Mutagenic activity of chemicals has been analysed with different plant systems such as Allium cepa (Fiskesjo, 1997), Vicia faba (Koppen and Verschaeve, 1996), Trifolium repens (Citterio et al., 2002), and Tradescantia virginiana (Fomin et al., 1999). These novel technologies offer added value compared with classical testing with whole organisms because they provide information concerning the molecular basis of exposure "molecular signatures" and act as "early warning" signals, enabling a more robust environmental monitoring than has ever been achieved previously (Mussali-Galante et al., 2013). Hence, the aim of this study is to evaluate the genotoxic effects of exposure of plants to heavy metals and polycyclic aromatic hydrocarbons from dumpsite, mechanic workshop and metal scrap site in Lagos using their DNA as biomarker.

\section{MATERIALS AND METHODS}

Sample Collection and Preparation: Three sampling sites influenced by different types of anthropogenic activities and a control with no known sources of pollution were selected for this study in Lagos. These sites are mechanic workshop, municipal dumpsite and metal scrap sites, and control site (Botanical garden of University of Lagos). Plants were collected from these sites and properly labeled before transportation to the laboratory, well preserved in air tight polythene bags and silica gel. The plants samples include: Musa acuminata (banana), Jatropha curcas (barbados nut), Carica papaya (pawpaw), Axonopus compressus (carpet grass), Sida acuta (wireweed), and Eleucine indica (crabgrass or crowfoot grass).

Soil samples for PAH determination were collected with a stainless-steel hand trowel, while plastic was used for collection of samples for heavy metal determination $(0-30 \mathrm{~cm})$. The stainless hand trowel and plastic were cleaned thoroughly to prevent cross contamination. Samples for PAHs were packed in pre-cleaned aluminum foil, which was previously solvent rinsed and dried at $80^{\circ} \mathrm{C}$. Polyethylene bags were used for packing soils for heavy metal determination. Samples for metals and soil characteristics determination were air-dried in the laboratory after manual removal of stones, twigs and other large materials then ground in a porcelain mortar and passed through a 2-mm sieve. PAH 
samples were preserved on ice and kept in the refrigerator prior to extraction and analyses.

Plants DNA Extraction and Analyses: The extraction of DNA from plants was carried out as described by Khanuja et al., (1999) using CTAB buffer, 2\% of CTAB, 20mM EDTA (Ethylenediaminetetracetic acid), 40ml EDTA, stock (0.5M), 76\% ethanol, and $0.2 \%$ mercaptoethanol. $0.8 \%$ agarose gel was made with $0.1 \mu \mathrm{l}$ of ethidium bromide $(10 \mathrm{mg} / \mathrm{ml})$ per 10 mlsolution. The samples were loaded with $3 \mu 1$ buffer. 100 base pair DNA marker was used as standard. The brightness of the samples was matched with the dilutions of the ladder (Bustin, 2002). The extracted plant DNA samples were diluted to 200ng/ml with Tris EDTA buffer before electrophoresis. After electrophoresis, the degrees of DNA fragmentation were assessed under the ultraviolet light using a UV transilluminator. Fragmentation was scored visually based on pink fluorescence intensity and degree of smearing. The degree of fragmentation was expressed in percentages $(\%)$ relative to the control set at $0 \%$ (Chen et al., 2005). Determination of DNA Yield (Quantification) was by the formulae below:

Soil Digestion and Heavy metal Analyses: 0.1g sample of dried and homogenized soil was accurately weighed and digested with $2 \mathrm{ml} \mathrm{HNO}_{3}, 1 \mathrm{ml} \mathrm{\textrm {HClO } _ { 4 }}$ and $5 \mathrm{ml} \mathrm{HF}$ at a temperature of $90 \pm 1900 \mathrm{C}$ for $16 \mathrm{~h}$. The residue was then dissolved in $2 \mathrm{ml}$ of $4 \mathrm{~mol} / \mathrm{L}$ $\mathrm{HCl}$ and diluted to $10 \mathrm{ml}$ with deionized water and analyzed for the heavy metals $(\mathrm{Cu}, \mathrm{Zn}, \mathrm{Pb}, \mathrm{Cr})$ by inductively coupled plasma-atomic emission spectrometry (ICP-AES) (Adesuyi et al., 2018).

Determination of Polycyclic Aromatic Hydrocarbons (PAHs) in Soils: $5 \mathrm{~g}$ of the air-dried soil samples were extracted in $20 \mathrm{ml}$ of $\mathrm{n}$-hexane, $99.99 \%$. The mixtures were shaken using a mechanical shaker for 24 hours and left to for 60 minutes at room temperature and filtered and the GC/MS analysis of chromatographic model: 7890A was done on agilent technologies interfaced with Mass Selective Detector model: 5975C9 (MSD).

Statistical Analysis: Analysis of variance (ANOVA) of the DNA yield and fragmentation of polluted sites and control sites were done using Microsoft excel and Graph pad 6.0 software package.

\section{RESULTS AND DISCUSSION}

DNA yield of plants from the different sites: The DNA content of plants collected from polluted and control sites in this study is presented in table 1 . Musa acuminata from the control site had DNA content of $273.97 \mathrm{ng} / \mu \mathrm{l}$ while that from the polluted site had a DNA content of $342.10 \mathrm{ng} / \mu \mathrm{l}$. Similarly, the quantity of DNA in Jatropha curcas from the control site was $220.35 \mathrm{ng} / \mu \mathrm{l}$ while that from the polluted site was $1017.18 \mathrm{ng} / \mu 1$. The results of DNA analysis of plant samples from the dump site in this study showed that, Carica papaya from the control site had DNA content of $736.83 \mathrm{ng} / \mu \mathrm{l}$ while DNA could not be quantified in Carica papaya of the polluted plant which can be attributed to the higher accumulation of pollutants in their tissues. Axonopus compressus from the polluted dump site had higher DNA content of $1230.98 \mathrm{ng} / \mu \mathrm{l}$ than plant from nonpolluted site with $224.78 \mathrm{ng} / \mu 1$.

DNA contents varied according to pollutant's site, with higher significant increase in DNA contents across all the polluted sites which is believed to be induced by the heavy metals or any of the other pollutants. It's a plant response to heavy metal stress and probably represents a mechanism to overcome the metal toxicity. This hypothesis is supported by different observations on plant behaviours under stress conditions; for example, it was reported that Euphorbia and Iris intra-and inter-specific variation in genome size along with polyploidy provides tolerance to extreme climates (Citterio et al., 2003). DNA content variation is considered of developmental and adaptive importance via its effects on parameters such as cell volume, time of mitotic cycle and duration of meiosis (Cavallini and Natali, 1991; Citterio et al., 2003). It has also been reported that certain PAH metabolites interact with deoxyribonucleic acid (DNA) and are genotoxic to them (Yang et al., 2018). The result of this study contradicts the work of Eliwa and Kamel (2013) in which solid waste pollution gave the highest reduction in DNA and RNA content of Olive plants.

Table 1: DNA yield (ng/ $\mu 1)$ of plant samples from polluted and control sites

\begin{tabular}{llll}
\hline Site & Plants & Control Polluted site \\
\hline Mechanic & Musa acuminata & 273.97 & 342.10 \\
Workshop & Jatropha curcas & 220.35 & 1017.18 \\
Dumpsite & Carica papava & 736.83 & ND \\
& Axanopus compressus & 224.78 & 1230.98 \\
Metal & Sida acuta & 451.19 & 693.40 \\
Scrap site & Eleucine indica & 306.08 & 385.31 \\
\hline \multicolumn{4}{c}{ ND means Not Detected }
\end{tabular}

DNA Fragmentation Index of Plants from Different Sites: Toxic and mutagenic effects of heavy metal contaminated soil on the plant system have been reported by Siddiqui $(2012 ; 2015)$. The result of the DNA fragmentation indicates that plants from the mechanic workshop had higher fragmentation indices than those from the control sites (table 2). Similarly, the fragmentation index of DNA extracted from 
Axonopus compressus from the dump site (70\%) was higher than that from the control site $(5 \%)$. Also, the fragmentation index of DNA extracted from Eleucine indica collected from the polluted metal area (45\%) was higher than that from the control site $(5 \%)$. Heavy metals have been reported to act on DNArepair enzymes, either by modifying the protein structure of the enzymes, or by reducing the production of the enzymes at the transcription level which could also lead to chromosomal aberrations in mitotic cells (Jaishanker et al., 2014). Siddiqui (2015) reported Cicer grown in soil polluted with heavy metals having several chromosomal abnormalities in mitotic cells such as sticky chromosome, fragments, precocious separation and laggard. Among these abnormalities precocious separation (PS) was the most frequently observed chromosomal aberration in the Cicer. In human PAH exposures, in addition to causing DNA adduct formation, also induce oxidative stress that provokes mutation (Ewa and Danuta, 2017). If DNA repair mechanisms work insufficiently, the result is the accumulation of mutations in DNA, which may induce carcinogenesis. Activation of several molecular and cellular responses is associated with genes involved in apoptosis, cell-cycle control and DNA repair (Castorena-Torres et al., 2008).

Table 2: Plant Fragmentation Index and Remarks

\begin{tabular}{|c|c|c|c|c|c|}
\hline \multirow[t]{2}{*}{ Site } & \multirow[t]{2}{*}{ Plant sample } & \multirow{2}{*}{\multicolumn{2}{|c|}{$\begin{array}{l}\text { Fragmentation Index (\%) } \\
\text { Pollute Control }\end{array}$}} & \multicolumn{2}{|c|}{ Remarks } \\
\hline & & & & Polluted & Control \\
\hline Mechanic & Musa acuminata & 15 & 10 & Moderate & Mild \\
\hline Workshop & Jatropha curcas & 50 & 5 & Severe & Mild \\
\hline Municipal & Carica papava & $\mathrm{ND}$ & $40 \%$ & $\mathrm{ND}$ & Moderate \\
\hline Dumpsite & Axonopus compressus & $70 \%$ & 5 & Severe & Mild \\
\hline Metal & Sida acuta & $\mathrm{ND}$ & 35 & ND & Moderate \\
\hline scrap site & Eleucine indica & 45 & 5 & Severe & Mild \\
\hline
\end{tabular}

It was observed that the DNA of samples from the mechanic workshop, dumpsite and metal area were smeared unlike those from the control site (Plate 1). The appearance or disappearance of new bands can be attributed either to alternation in the structural genes, or changes in the expression of regulatory genes due to mutagenic effect of heavy metals or other pollutants making up the polluted soil.

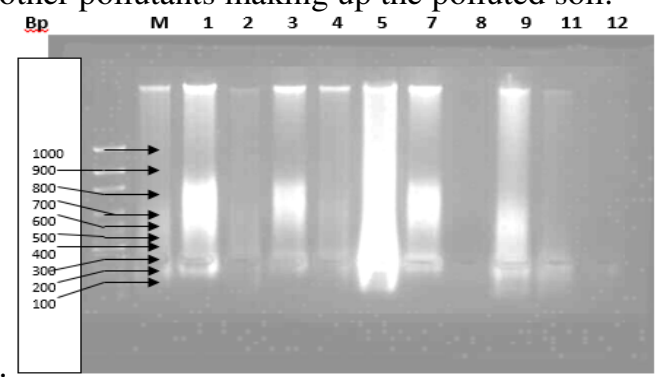

PLATE 1: Gel photo documentation picture of the DNA extracts of sample
M=Marker 100 base pair DNA ladder Plant 1-Musa acuminata (control); Plant 2-Musa acuminata (polluted); Plant 3-Jatropha curcas (control); Plant 4-Jatropha curcas (polluted); Plant 5Carica papaya (control); Plant 6-Carica papaya (polluted); Plant 7- Axonopus compressus (polluted); Plant 8-Axonopus compressus (control); Plant 9-Sida acuta (control); Plant 10-Sida acuta (polluted); Plant 11-Eleucine indica (polluted); Plant 12-Eleucine indica (control

Mutational events occurring in the regulatory genes may lead to inhibition or constitutive expression of concerned genes and this will result in the disappearance of some bands or changes in some band intensities i.e., heavy metals present in sewage water result in an increase in the transcription of several stress-induced genes and lead to the accumulation of their polypeptides (Zeid and Abou El Ghate, 2007).

Heavy Metals Level in Soil Samples: The heavy metal content of soil samples from different sites is shown in table 4. Copper, zinc and chromium were highest in the dumpsite followed by the metal area and were lowest in the mechanic workshop. Copper was highest in the dumpsite $(2.304 \mathrm{mg} / \mathrm{kg})$ and lowest in the mechanic workshop $(0.014 \mathrm{mg} / \mathrm{kg})$. Similarly, zinc was highest in the dumpsite $(5.146 \mathrm{mg} / \mathrm{kg})$ and lowest in the mechanic workshop $(1.990 \mathrm{mg} / \mathrm{kg})$. Lead had the highest amount of heavy metals of $0.401 \mathrm{mg} / \mathrm{kg}$ in the metal area and the lowest with $0.032 \mathrm{mg} / \mathrm{kg}$ in the mechanic workshop. Chromium was highest in the dumpsite with a of $0.022 \mathrm{mg} / \mathrm{kg}$ and lowest in the mechanic workshop with 0.002 $\mathrm{mg} / \mathrm{kg}$. Statistical evaluation with the two-way analysis of variance (ANOVA) showed that there were differences in the quantity of heavy metals from mechanic workshop to dumpsite $(\mathrm{p}<0.05)$.

Table 3: Concentration $(\mathrm{mg} / \mathrm{kg})$ of Heavy Metals in Polluted Sites

\begin{tabular}{lllll}
\multicolumn{5}{c}{ (Each value is a mean of three determinations) } \\
\hline Site & $\mathbf{C u}$ & $\mathbf{Z n}$ & $\mathbf{P b}$ & $\mathbf{C r}$ \\
Dumpsite & 2.304 & 5.146 & 0.098 & 0.022 \\
Metal scrap site & 1.304 & 2.709 & 0.401 & 0.018 \\
Mechanic Workshop & 0.014 & 1.990 & 0.032 & 0.002 \\
\hline
\end{tabular}

Polycyclic Aromatic Hydrocarbons (PAHs) in Soils: The soil from the dumpsite in table 5 had the least PAHs, then the metal site, mechanic workshop has the highest. It was also observed that benzo[a]pyrene, benz[e]acephenanthrylene, benzo[e]pyrene, indeno[1,2,3-cd]pyrene and benzo[ghi]pyrelene were detected in samples from the mechanic workshop and the metal area. However, triphenylene was only present in the metal area while phenanthrene, and pyrene were present only in samples from the mechanic workshop. Statistical analysis showed there were significant differences between the PAHs content of soil in mechanic to metal area and to 
dumpsite from all the study sites $(\mathrm{p}<0.05)$. BenachSzott et al. (2014) reported that the introduction of PAHs (anthracene, fluorene, pyrene and chrysene) to soil samples resulted in a change in some of the quality parameters of humic acids that were isolated from the soil samples that were incubated for 180 and 360 days. Polycyclic aromatic hydrocarbons released to soil will adsorb to particulate matter where they might be slowly degraded by microbial activity or transported by surface runoff. In aquatic systems, PAHs generally adsorb to suspended matter or sediments, where they tend to persist (Igwe and Ukaogo, 2015). The toxicity of PAHs to aquatic organisms is affected by metabolism and photooxidation. Abdel-Shafy and Mansour (2016) reported PAH to be generally more toxic in the presence of ultraviolet light with moderate to high acute toxicity to aquatic life and birds. PAHs in soil are unlikely to exert toxic effects on terrestrial invertebrates, except when the soil is highly contaminated. Adverse effects on these organisms include tumors, reproduction, development, and immunity (Lawal, 2017).

Table 5: PAHs content of soil samples from the study sites

\begin{tabular}{|c|c|c|c|}
\hline Compounds & $\begin{array}{l}\text { Mechanic } \\
\text { workshop } \\
\text { (mg/lg) }\end{array}$ & $\begin{array}{l}\text { Dump } \\
\text { site } \\
\text { (mg/lg) }\end{array}$ & $\begin{array}{l}\text { Metal } \\
\text { Area } \\
(\mathrm{mg} / \mathrm{g})\end{array}$ \\
\hline Bipherrylene & 0.00 & $\mathrm{ND}$ & $\mathrm{ND}$ \\
\hline Acenaphthene & $\mathrm{ND}$ & ND & ND \\
\hline Fluorene & 0.00 & ND & 0.00 \\
\hline Phenanthrene, & 0.03 & 0.00 & ND \\
\hline Flvoranthene & 0.00 & $\mathrm{ND}$ & 0.00 \\
\hline Pyrene & 0.07 & ND & 0.00 \\
\hline Triphenylene & 0.00 & ND & 0.01 \\
\hline Benzo[a]pyrene & 0.06 & 0.00 & 0.02 \\
\hline Benze [e] acephenanthrylene & 0.07 & 0.00 & 0.01 \\
\hline Benzo[e]pyrene & 0.03 & 0.00 & 0.08 \\
\hline Indeno $[1,2,3$-cd $]$ pryrene & 0.03 & ND & 0.10 \\
\hline Benzo[ghilperylene & 0.02 & ND & 0.05 \\
\hline TOTAL & 0.31 & 0.00 & 0.27 \\
\hline
\end{tabular}

N.D means Not Detected; Ppm means part per million

The chromatograms of the PAHs in the different soils are shown below

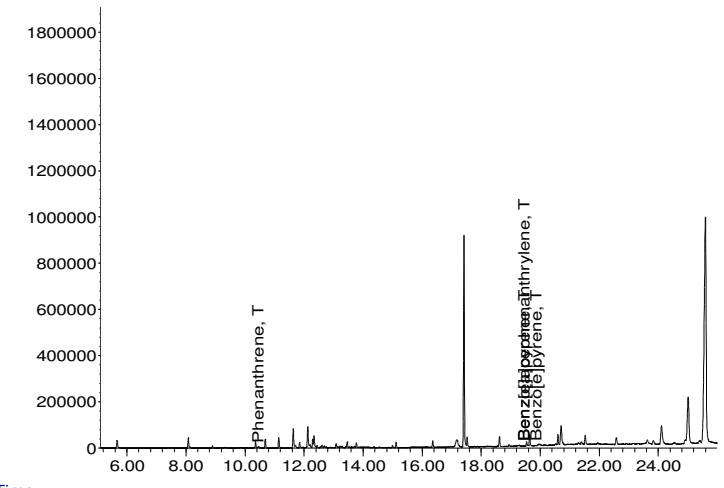

Fig 1: Chromatogram of Polycyclic aromatic hydrocarbons in Dumpsite

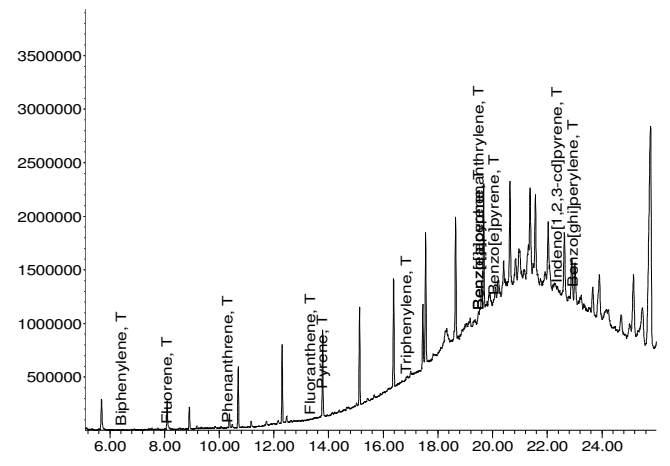

Fig 2: Chromatogram of Polycyclic aromatic hydrocarbons in Mechanic workshop

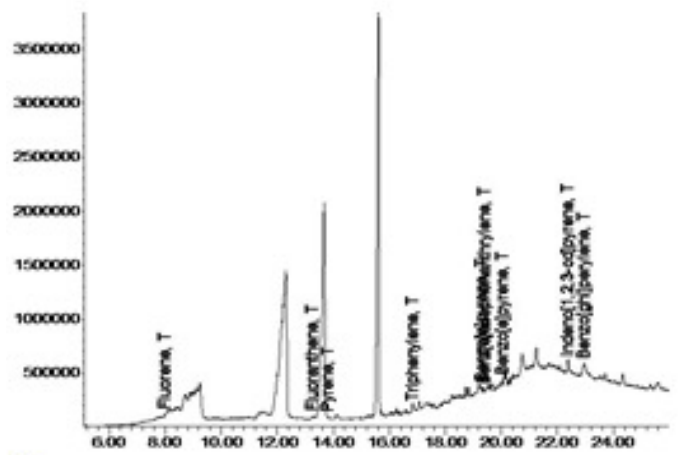

Fig 3: Chromatogram of Polycyclic aromatic hydrocarbons in Metal Area

Conclusion: The results of this experiment carried out showed that plant in polluted sites had more DNA yield and fragmentation than those from non-polluted sites, more smearing of DNA was also identified in polluted plants than those from control sites. The results of this study indicate that dumpsite, mechanic workshop and metal scrap sites are potential sources of PAH and toxic metal, which can pose serious human health and ecological risks.

\section{REFERENCES}

Abdel-Shafy, HI; Mansour, MSM. (2016). A review on polycyclic aromatic hydrocarbons: Source, environmental impact, effect on human health and remediation. Egyptian J. Petroleum 25: 107123.

Adesuyi, AA; Njoku, KL; Akinola, MO. (2015). Assessment of heavy metals pollution in soils and vegetation around selected industries in Lagos State, Nigeria. J. Geosci. Environ. Protect. 3 (07): 11.

Adesuyi, AA; Njoku, KL; Akinola, MO; Jolaoso, AO. (2018). Biomonitoring of Heavy Metals Level in Wetland Plants of Lagos Lagoon, 
Nigeria. J. Appl. Sci. Environ. Manage. 22(9): 1489-1498.

Adesuyi, AA; Nnodu, VC; Njoku, KL; Jolaoso, A (2016) Evaluation of Industrial Discharge Point Source Pollution in Ikeja Industrial Estate, Ikeja, Lagos, Nigeria. Unilag J. Med. Sci. Technol. 4 (2): $29-46$.

Banach-Szott, M; Debska, B; and Rosa, EJ. (2014). Effect of soil pollution with polycyclic aromatic hydrocarbons on the properties of humic acids. Soils Sediments, 14: 1169-1178.

Bickham, JW; Shabeg, S; Paul, DN; Lounes, C; Raghbir, A. (2000). Effects of chemical contaminant on genetic diversity in natural populations; implication for biomonitoring and ecotoxicology. Mutation Research / Review in Mutation Research, 463: 33-51

Briton, LN (1984). Microbial degradation of alphatic hydrocarbons in microbial degradation of organic compounds. Microbiology Series, $13: 765-770$

Bustin, SA. (2002). Quantification of RNA, DNA using real time reverse transcription PCR (RTPCR): Trends and problems. J. Mol. Endocrinol 29: 23-29.

Castorena-Torres, F; Bermudez de Leon, M; Cisneros, B; Zapata-Perez, O; Salinas, JE; Albores, A. (2008). Changes in gene expression induced by polycyclic aromatic hydrocarbons in the human cell lines HepG2 and A549. Toxicol In Vitro., 22(2):411-421.

Cavallini, A; Natali, L. (1991). Intraspecific variation of nuclear DNA content in plant species. Caryologia 44(1), 93-107.

Chen, Z; Wang, J; Mattew, L. (2005). Endogenous endonuclease-induced DNA fragmentation: an early event in cell-mediated cytolisis. Proceedings of the National Academy of sciences United States of America, 102: 49784983.

Citterio, S; Aina, R; Labra, M; Ghiani, A; Fumagalli, P; Sgorbati, S; Santagostino, A. (2002). Soil genotoxicity: a new strategy based on biomolecular tools and plants bioindicators. Environ. Sci. Technol. 36, 2748-2753.
Citterio, S; Santagostino, A; Fumagalli, P; Prato, N; Ranalli, P; Sgorbati, S. (2003). Heavy metal tolerance and accumulation of $\mathrm{Cd}, \mathrm{Cr}$ and $\mathrm{Ni}$ by Cannabis sativa L. Plant and Soil, 256: 243-252.

Eliwa, AM; Kamel, EAR. (2013). Olive Plants (Olea europaea L.) as a Bioindicator for Pollution. Pakistan J. Biol. Sci. 16: 551-557.

EPA (2000). Innovative remediation technologies: field scale demonstration projects in North America. 2nd Ed. Environmental Protection Agency. National Service Center for Environmental Publications (NSCEP), 139 pp.

Ewa, B; Danuta, M-S. (2017). Polycyclic aromatic hydrocarbons and PAH-related DNA adducts. $J$ Appl Genet., 58(3): 321-330.

Fetzer, J.C. (2000). The chemistry and analysis of the large Polycyclic aromatic hydrocarbons. Polycyclic Aromatic Compounds, 2: 143-145.

Fiskesjo, G., (1997). Allium test for screening chemicals; evaluation of cytological parameters. In: Wang, W., Gorsuch, J.W., Hughes, J.S. (Eds.), Plants for Environmental Studies. Lewis Publishers, New York, pp. 307-333.

Fomin, A; Paschke, A; Arndt, U. (1999). Assessment of the genotoxicity of mine-dump material using the tradescantiastamen hair (trad-shm) and the tradescantia-micronucleus (trad-shm) bioassay. Mutation Research. 426: 173-181.

Grant, WF. (1994). The present status of higher plant bioassay for the detection of environmental mutagens. Mutat. Res. 310, 175-185.

Igwe, JC; Ukaogo, PO. (2015). Environmental Effects of Polycyclic Aromatic Hydrocarbons. $J$. Nat. Sci. Res. 5(7): 117-131.

Jaishankar, M; Tseten, T; Anbalagan, N; Mathew, BB; Beeregowda, KN. (2014). Toxicity, mechanism and health effects of some heavy metals. Interdiscip Toxicol. 7(2): 60-72.

Khanuja, P; Shasany, A; Kuma, S. (1999). Rapid isolation of DNA from dry and fresh samples of plants producing large amounts of secondary metabolites and essential oils. Plant Molecular Biology, 17: 1-7.

Knasmuller, S; Gottmann, E; Steinkellner, H; Fomin, A; Pickl, C; Paschke, A; God, R; Kundi, M 
(1998). Detection of genotoxic effects of heavy metal contaminated soils with plant bioassays. Mutation Res. 420: 37-48.

Kovalchuk, I., Kovalchuk, O. (2008). Transgenic Plants as Sensors of Environmental Pollution Genotoxicity. Sensors, 8(3): 1539-1558.

Labra, T; Di Fabio, T; Grassi, F; Regondi, SMG; Bracale, M; Vannini, C; Agradi, E. (2003). AFLP analysis as biomarker of exposure to organic and inorganic genotoxic substances in plants. Chemosphere, 52: 1183-1188.

Lawal, AT. (2017). Polycyclic aromatic hydrocarbons: A review. Cogent Environmental Science, $3(1)$, https://doi.org/10.1080/23311843.2017.1339841.

Minissi, S; Lombi, E. (1997). Heavy metal contents and mutagenic activity, evaluated by faba micronucleus test, of Tiber river sediments. Mut. Res. Gen. Toxicol. Environ. Mutage.393, 17-21.

Mussali-Galante, P; Tovar-Sanchez, E; Valverde, M; Rojas Del Castillo, E. (2013). Biomarkers of Exposure for Assessing Environmental Metal Pollution: from Molecules to Ecosystems. Revista Intern. Contam. Ambiental. 29 (1) $117-$ 140.

Njoku, KL; Yussuf, A; Akinola, MO; Adesuyi, AA; Jolaoso, AO; Adedokun, AH. (2016). Mycoremediation of petroleum hydrocarbon polluted soil by Pleurotus pulmonarius. Ethiopia J Environ Stud Manage 9 (Suppl 1): 865-875.

NRC (1987). Committee on biological markers of the National Research Council. Biological markers in environmental health research. Environ. Health Perspect. 74: 3-9.

NRC (1989). Biological markers in reproductive toxicology. National Research Council. Washington, DC. National Academy Press, 420 pp
Shen, Z; Wang, C; Chen, H; Chua, H. (2002). Lead phytoextraction from contaminated soil with high biomass plant species. J Environ Quality, 31(6): 1893-1900.

Siddiqui, S. (2015). DNA damage in Cicer plant grown on soil polluted with heavy metals. $J$. King Saud Univ. - Sci. 27: 217-223.

Siddiqui, S., (2012). Lead induced genotoxicity in Vigna mungo Var. HD-94. J. Saudi Soc. Agri. Sci. 11: 107-112.

Valavanidis, A; Vlachogianni T. (2010). Metal pollution in ecosystems. Ecotoxicology studies and risk assessment in the marine environment. Sci. Adv. Environ. Toxicol. Ecot. Issues. chemtox-ecotox.org/wp/ content/uploads/2010/01/02-Metals17_01_2010.pdf [on line].

Valverde, M; Rojas E. (2009). Environmental and occupational biomonitoring using the comet assay. Mutat Res. 681: 93-109.

Vanden-Heuvel, J; Davis, J. (1999). Molecular approaches to identify exposure and risk to specific environmental pollutants. Biomarkers 4, 93-105.

Wang, WC; Freemark, K. (1995). The use of plants for environmental monitoring and assessment. Ecotox Environ Safety. 30:289-301.

Wozniak, K; Blasiak, J. (2003). In vitro genetoxicity of lead acetate; induction of single and double DNA stranded break and DNA -Protein crosslinks. Mut. Res. Gen. Toxicol. Environ. Mutage. 535: 127-139.

Yang, Y; Pengcheng, W; Yuxiang, C; Yinsheng, W. (2018). Chemical Analysis of DNA Damage. Anal Chem. 2018 Jan 2; 90(1): 556-576.

Zeid, IM; Abou El Ghate, H.M. (2007). Effect of Sewage Water on Growth, Metabolism and Yield of Bean. J Biol. Sci. 7: 34-40 